Article

\title{
Hydrogen Production from Methane Cracking in Dielectric Barrier Discharge Catalytic Plasma Reactor Using a Nanocatalyst
}

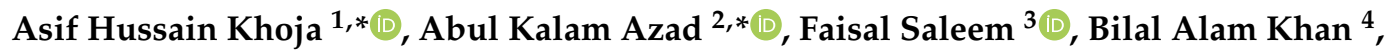
Salman Raza Naqvi ${ }^{5}{ }^{(0)}$, Muhammad Taqi Mehran ${ }^{5}{ }^{(-)}$and Nor Aishah Saidina Amin ${ }^{6}$

1 Fossil Fuels Laboratory, Department of Thermal Energy Engineering, US-Pakistan Centre for Advanced Studies in Energy (USPCAS-E), National University of Sciences \& Technology (NUST), Sector H-12, Islamabad 44000, Pakistan

2 School of Engineering and Technology, Central Queensland University, 120 Spencer Street, Melbourne 3000, VIC, Australia

3 Department of Chemical and Polymer Engineering, University of Engineering and Technology, Lahore 38000, Faisalabad Campus, Pakistan; h.faisalsaleem@gmail.com

4 Department of Applied Science and Technology, Politecnico di Torino, Corso Duca degli Abruzzi, 24, 10129 Torino, Italy; bilal.khan@polito.it

5 School of Chemical and Materials Engineering, National University of Sciences \& Technology (NUST), Sector H-12, Islamabad 44000, Pakistan; salman.raza@scme.nust.edu.pk (S.R.N.); taqimehran@scme.nust.edu.pk (M.T.M.)

6 Chemical Reaction Engineering Group, School of Chemical \& Energy Engineering, Faculty of Engineering, University Technology Malaysia (UTM), Skudai, Johor Bahru 81310, Malaysia; noraishah@cheme.utm.my

* Correspondence: asif@uspcase.nust.edu.pk (A.H.K.); a.k.azad@cqu.edu.au (A.K.A.); Tel.: +92-51-8865343 (A.H.K.)

Received: 9 October 2020; Accepted: 11 November 2020; Published: 13 November 2020

\begin{abstract}
The study experimentally investigated a novel approach for producing hydrogen from methane cracking in dielectric barrier discharge catalytic plasma reactor using a nanocatalyst. Plasma-catalytic methane $\left(\mathrm{CH}_{4}\right)$ cracking was undertaken in a dielectric barrier discharge (DBD) catalytic plasma reactor using $\mathrm{Ni} / \mathrm{MgAl}_{2} \mathrm{O}_{4}$. The $\mathrm{Ni} / \mathrm{MgAl}_{2} \mathrm{O}_{4}$ was synthesised through co-precipitation followed customised hydrothermal method. The physicochemical properties of the catalyst were examined using $\mathrm{X}$-ray diffraction (XRD), scanning electron microscopy-energy dispersive X-ray spectrometry (SEM-EDX) and thermogravimetric analysis (TGA). The Ni/ $\mathrm{MgAl}_{2} \mathrm{O}_{4}$ shows a porous structure spinel $\mathrm{MgAl}_{2} \mathrm{O}_{4}$ and thermal stability. In the catalytic-plasma methane cracking, the $\mathrm{Ni} / \mathrm{MgAl}_{2} \mathrm{O}_{4}$ shows $80 \%$ of the maximum conversion of $\mathrm{CH}_{4}$ with $\mathrm{H}_{2}$ selectivity $75 \%$. Furthermore, the stability of the catalyst was encouraging $16 \mathrm{~h}$ with $\mathrm{CH}_{4}$ conversion above $75 \%$, and the selectivity of $\mathrm{H}_{2}$ was above $70 \%$. This is attributed to the synergistic effect of the catalyst and plasma. The plasma-catalytic $\mathrm{CH}_{4}$ cracking is a promising technology for the simultaneous $\mathrm{H}_{2}$ and carbon nanotubes (CNTs) production for energy storage applications.
\end{abstract}

Keywords: hydrogen production; methane cracking; $\mathrm{DBD}$ plasma reactor; $\mathrm{MgAl}_{2} \mathrm{O}_{4} ; \mathrm{CNTs}$

\section{Introduction}

The atmosphere is heavily polluted due to the urbanisation and commercialisation throughout the globe. It causes serious greenhouse gases (GHGs) emissions, more specifically, the carbon dioxide $\left(\mathrm{CO}_{2}\right)$ and methane $\left(\mathrm{CH}_{4}\right)$ along with other volatile compounds. Various techniques have been applied to treat the GHGs to reduce harmful emissions for sustainable development. One of the exciting techniques is to utilise the GHGs for producing zero-emission fuel, which is currently under 
investigation throughout from the last couple of decades. It is an essential step to reduce the GHG concentration in the atmosphere as well as a sustainable approach for fuel synthesis [1-3]. Previous studies revealed that $\mathrm{CH}_{4}$ is one of the prominent components of GHG with a total share of $16 \%$ in the environment usually emitted from petroleum processing, waste management and agriculture activities [4].

On the other hand, $\mathrm{CH}_{4}$ is also the principal constituent (76 wt\%) of natural gas (NG) which reserves are abundantly available in underground. The utilisation of $\mathrm{CH}_{4}$ has various routes as fuel both in domestic and industrial processes. One of the most sustainable and attractive ways to utilise $\mathrm{CH}_{4}$ is to produce syngas and hydrogen $\left(\mathrm{H}_{2}\right)$ along with co-reactants such as $\mathrm{O}_{2}, \mathrm{H}_{2} \mathrm{O}$, and $\mathrm{CO}_{2}[5,6]$. The popular routes for $\mathrm{CH}_{4}$ mitigation are thermocatalytic processes such as thermal decomposition of methane as shown in the below reaction (R1), methane partial oxidation [7], methane dry reforming [8-10] and methane steam reforming [11] in thermal reactors. The higher energy input for elevated temperatures makes the thermal reactors economically challenging for this process $[12,13]$. Various techniques have been employed to overcome the shortfalls to make the process viable $[14,15]$.

$$
\mathrm{CH}_{4} \rightarrow \mathrm{C}+2 \mathrm{H}_{2} \Delta \mathrm{H}^{\circ} 5^{\circ} \mathrm{C}=75 \mathrm{~kJ} \mathrm{~mol}^{-1}
$$

In recent days, various plasma systems are used for the processing of the methane carking as well as other oxidative reactions using microwave plasma, spark plasma $[8,10,16]$ and nonthermal plasmas (NTPs) like dielectric barrier discharge (DBD) and silent discharges. NTP seeks attention for gas processing, especially the DBD cold plasma reactor is one of the promising techniques $[8,12]$. The DBD plasma reactor has some useful characteristics from low-temperature operation to accessible upscaling opportunities as compared to thermal plasma [8,17]. More significant aspects of the DBD plasma for gas processing has been reported in an extensive review by Ramses and Bogaerts [12]. In addition, the DBD plasma has been successfully utilised for $\mathrm{CH}_{4}$ cracking with efficient conversion and significant $\mathrm{H}_{2}$ yield [18-20]. The hydrogen is the next-generation future fuel due to the recent developments in hydrogen-based fuel cell technologies [21]. The DBD plasma-based methane cracking has been reported in several studies aiming for cleaner production of $\mathrm{H}_{2}$. However, the conversion efficiency and cleaner $\mathrm{H}_{2}$ is always challenging in the DBD plasma reactor for a longer time on streams [6,22].

To improve the conversion of $\mathrm{CH}_{4}$, the various catalysts have been employed in the catalytic DBD plasma. The most valuable catalysts for plasma catalytic DBD methane cracking are $\mathrm{Ni} / \gamma-\mathrm{Al}_{2} \mathrm{O}_{3}, \gamma-\mathrm{Al}_{2} \mathrm{O}_{3}, \mathrm{Pd} / \mathrm{SiO}_{2}, \mathrm{Pd} / \mathrm{TiO}_{2}, \mathrm{Pd} / \mathrm{Al}_{2} \mathrm{O}_{3}$ [23], $\mathrm{Pt} / \gamma-\mathrm{Al}_{2} \mathrm{O}_{3}$ [24], $\mathrm{ZnO}, \mathrm{ZnCr}_{2} \mathrm{O}_{4}, \mathrm{Cr}_{2} \mathrm{O}_{3}$ [25]. The improvement in the conversion of $\mathrm{CH}_{4}$ as well as enhanced product selectivity been a witness in various referenced studies [25]. Plasma-catalysis drives scope on improving the selectivity of targeted products which is very important for $\mathrm{CH}_{4}$ cracking process. The magnesium aluminate $\left(\mathrm{MgAl}_{2} \mathrm{O}_{4}\right)$ as a catalyst has been investigated for various reforming process $[9,26,27]$ as well as plasma catalytic methane dry reforming in previous studies. It demonstrated a substantial improvement in conversion of reactants and product distribution, especially on the $\mathrm{H}_{2}$ selectivity $[28,29]$. The nickel (Ni) impregnated $\mathrm{MgAl}_{2} \mathrm{O}_{4}$ can improve the $\mathrm{CH}_{4}$ conversion and $\mathrm{H}_{2}$ selectivity suppressing the recombination of methyl radicals [30]. The $\mathrm{MgAl}_{2} \mathrm{O}_{4}$ based catalyst has not been previously reported as its distinct properties such as high resistance to temperature, and mild plasma conditions are much suitable to use in plasma-based methane cracking processes. Therefore, it is seems meaning to incorporate the $\mathrm{Ni}$ impregnated $\mathrm{MgAl}_{2} \mathrm{O}_{4}$ in the DBD plasma reactor for methane cracking for hydrogen production and simultaneously it produces carbon nanotubes (CNTs) which are essential material for energy storage applications [31]. Plasma produces a very clean and well-structured CNTs for further application reported in various studies.

In this work, an experimental study has been conducted to the synthesis of a nanocatalyst $\left(\mathrm{Ni} / \mathrm{MgAl}_{2} \mathrm{O}_{4}\right)$ for $\mathrm{CH}_{4}$ cracking in fixed bed DBD plasma reactor for $\mathrm{H}_{2}$ and $\mathrm{CNTs}$ production. The catalyst was synthesised using the co-precipitation method followed by hydrothermal process. The catalyst is further characterised by X-ray diffraction (XRD), scanning electron microscopy (SEM), energy dispersive $\mathrm{X}$-ray spectrometry (EDX) and thermogravimetric analysis (TGA). Furthermore, 
the stability of the catalyst was examined for $16 \mathrm{~h}$ reaction time or time on stream (TOS). Finally, spent catalyst is further characterised using SEM, TGA and differential thermogravimetric (DTG) to investigate the formed CNTs over catalyst surface.

\section{Materials and Methods}

\subsection{Synthesis of $\mathrm{Ni} / \mathrm{MgAl}_{2} \mathrm{O}_{4}$}

The support $\mathrm{MgAl}_{2} \mathrm{O}_{4}$ was prepared through co-precipitation process supported by the hydrothermal method presented in Figure 1. Briefly, magnesium nitrate hexahydrate $\left(\mathrm{Mg}\left(\mathrm{NO}_{3}\right)_{2} \cdot 6 \mathrm{H}_{2} \mathrm{O}\right)$ (99.5\%, Sigma, St. Louis, MI, USA) and aluminium nitrate nonahydrate $\left(\mathrm{Al}\left(\mathrm{NO}_{3}\right)_{3} \cdot 9 \mathrm{H}_{2} \mathrm{O}\right)(99.5 \%$, Merck, NJ, USA) was dissolved in ACS reagent, ammonia solution (28.0\%) with the 2:1 molar ratio of $\mathrm{Mg}$ :Al. The nitrate solution was then combined to 0.01 molar citric acid (CA) solution using pipette at $60{ }^{\circ} \mathrm{C}$ on continuous stirring at a speed of $350 \mathrm{rpm}$. The ammonia is acting as a precipitating agent while citric acid is assisting control crystal growth and morphology. The nitrate solution is transferred to a polytetrafluoroethylene (PFTE) Teflon autoclave and kept in the furnace for $24 \mathrm{~h}$ at a temperature of $160^{\circ} \mathrm{C}$. Further, the sample has been washed using ethanol numerous times and deionised (DI) water for the removal of impurities. The prepared samples dried in the oven at a temperature of $120^{\circ} \mathrm{C}$ for $24 \mathrm{~h}$ to remove the moisture. The received derived sample was crushed and kept for calcination at $700{ }^{\circ} \mathrm{C}$ for $4 \mathrm{~h}$.

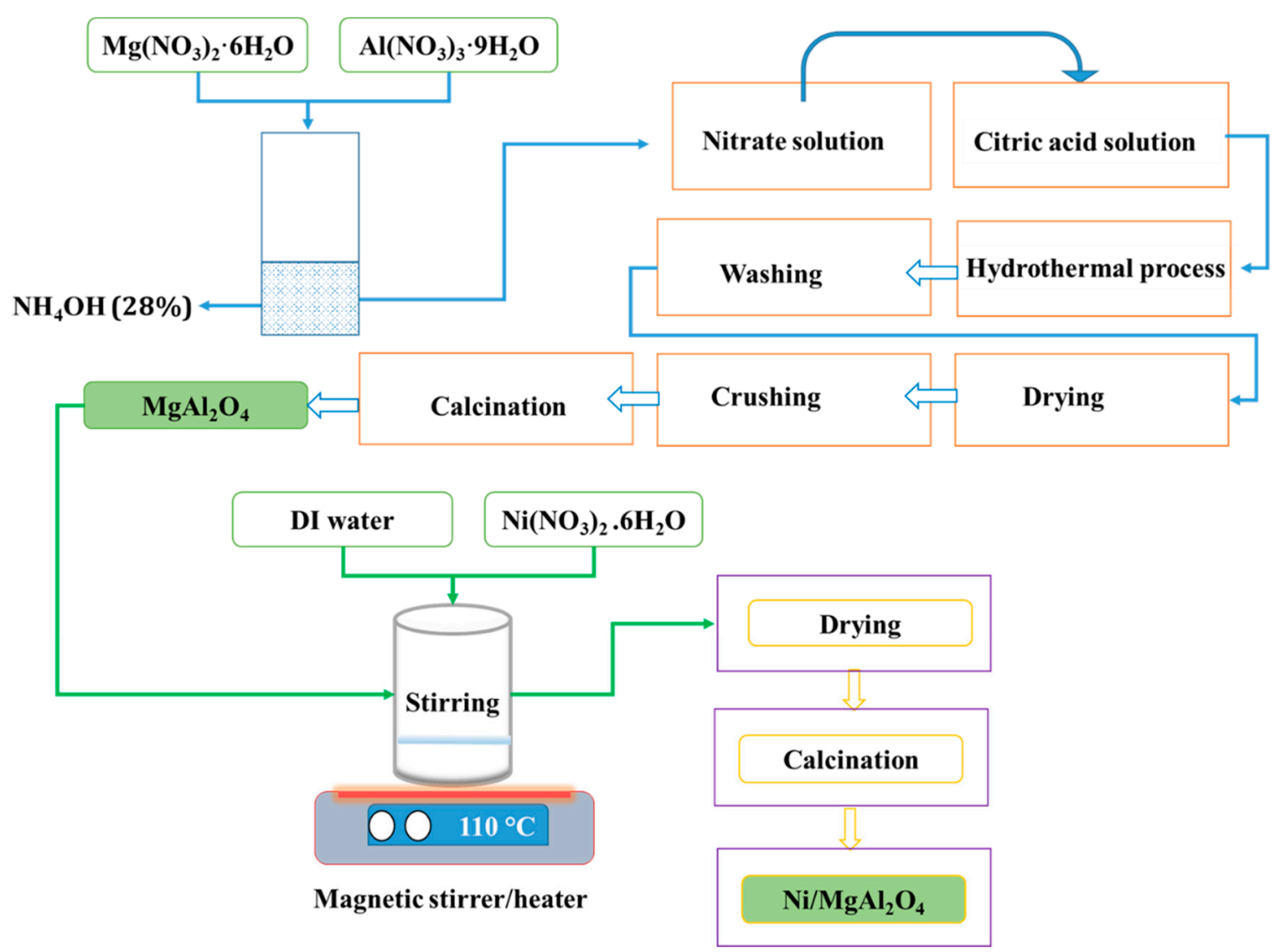

Figure 1. Schematic of $\mathrm{Ni} / \mathrm{MgAl}_{2} \mathrm{O}_{4}$ synthesis.

For Ni impregnation, wetness incipient impregnation technique has been employed. The precursor $(10 \mathrm{wt} \%)$. nickel nitrate hexahydrate $\left(\mathrm{Ni}\left(\mathrm{NO}_{3}\right)_{2} \cdot 6 \mathrm{H}_{2} \mathrm{O}\right)(99 \%$, Merck) was added to DI water to get 0.01 molar nitrate solution. The nitrate solution stirred for $10 \mathrm{~min}$ at $60^{\circ} \mathrm{C}$. The required amount of support $\mathrm{MgAl}_{2} \mathrm{O}_{4}$ was then combined to the nickel nitrate solution and stirring for three (3) hours at $110{ }^{\circ} \mathrm{C}$. The sample was kept in a furnace (CSF 1100, Carbolite, Cheshire, UK) for overnight about 10 to $12 \mathrm{~h}$ 
for drying. The dried sample was crushed and preserved in the furnace for $5 \mathrm{~h}$ at $700{ }^{\circ} \mathrm{C}$ to achieve the final catalyst for methane cracking application.

\subsection{Materials Characterisation}

The physicochemical properties of the synthesised catalyst are examined by several methods i.e., XRD, SEM-EDX and TGA. XRD was accomplished employing Bruker's X-ray Diffractometer (D8-Advance, MA, USA), using Cu- $k \alpha$ radiation $(40 \mathrm{kV}, 200 \mathrm{~mA})$. The crystallite size was analysed by Scherrer's equation [32]. After that, SEM was carried out using TESCAN VEGA 3 (Czech Republic), conducted at $20 \mathrm{kV} \mathrm{HV}$ and integrated with the beam of X-MaxN by Zeiss optics [13]. TGA 5500 (TA Instruments, Newcastle, DC, USA) was used to analyses the weight loss (\%) and differential thermogravimetric analysis (DTG) of the fresh catalyst. The sample $(10 \mathrm{mg})$ was loaded in a platinum pan and placed in the furnace at a heating rate of $10^{\circ} \mathrm{C} \mathrm{min}^{-1}$ under the $\mathrm{N}_{2}$ flow of $40 \mathrm{~mL} \mathrm{~min}^{-1}[30,33]$. Spent catalyst was characterised by SEM and TGA-DTG ((TA Instruments, Newcastle, DC, USA)) after $16 \mathrm{~h}$ TOS to investigate the morphological changes and CNT formation.

\subsection{Plasma-Catalytic Methane Cracking System}

The experimental setup for the catalytic-DBD reactor for $\mathrm{CH}_{4}$ cracking is as shown in Figure 2. The reactant $\mathrm{CH}_{4}(99.9 \%)$ flow rate was regulated by a mass flow meters/controller (MFC) (Alicat, Tucson, AZ, USA). The plasma power supply model CTP-2000K (Nanjing, China) incorporated with the high voltage regulator was used to produce plasma in the DBD reactor. The input voltage and input current were also monitored by Tektronix TDS 2012B oscilloscope (Beaverton, OR, USA) coupled with voltage probe Tek P6015A (Beaverton, OR, USA) [28]. The plasma reactor consists of an alumina tube having an inner diameter (ID) of $10 \mathrm{~mm}$ and the outer diameter (OD) of $12 \mathrm{~mm}$. The stainless steel rod with an inner diameter of $4 \mathrm{~mm}$ and $20 \mathrm{~cm}$ in length was utilised as a HV electrode while a mesh of aluminium is wrapped serving as a ground electrode. The prepared catalyst is loaded in the centre of the alumina tube hold by quartz wool. The gases were analysed by GC-TCD/FID (Agilent 6890N, Santa Clara, CA, USA). The GC column details are given in details here [34]. The HP PlotQ capillary column with configuration of $40 \mathrm{~m} \times 0.53 \mathrm{~mm}$ ID, $40 \mu \mathrm{m}$ was used to detect $\mathrm{CO}_{2}$ while Molsieve column with the configuration of $30 \mathrm{~m} \times 0.530 \mathrm{~mm}$ ID, $25 \mu \mathrm{m}$ used for detecting $\mathrm{H}_{2}$ and $\mathrm{CH}_{4}$, both the columns were connected to TCD. Another column HayeSep Q-Supelco with the configuration of $6 \mathrm{ft}$ $\times 1 / 8$ in. ID $\times 2.1 \mathrm{~mm}$ OD, $80 / 100$ mesh was employed as TCD $C_{2}-C_{6}$ back flashing. To separate the hydrocarbons ranging from $\mathrm{C}_{1}-\mathrm{C}_{6}$ were analysed by GS-Gaspro column having the configuration of $60 \mathrm{~m} \times 0.32 \mathrm{~mm}$ ID) detected to FID. Agilent supplied all the columns. The process parameters such as feed flow rates, power input and loading of prepared catalyst were maintained constant. 


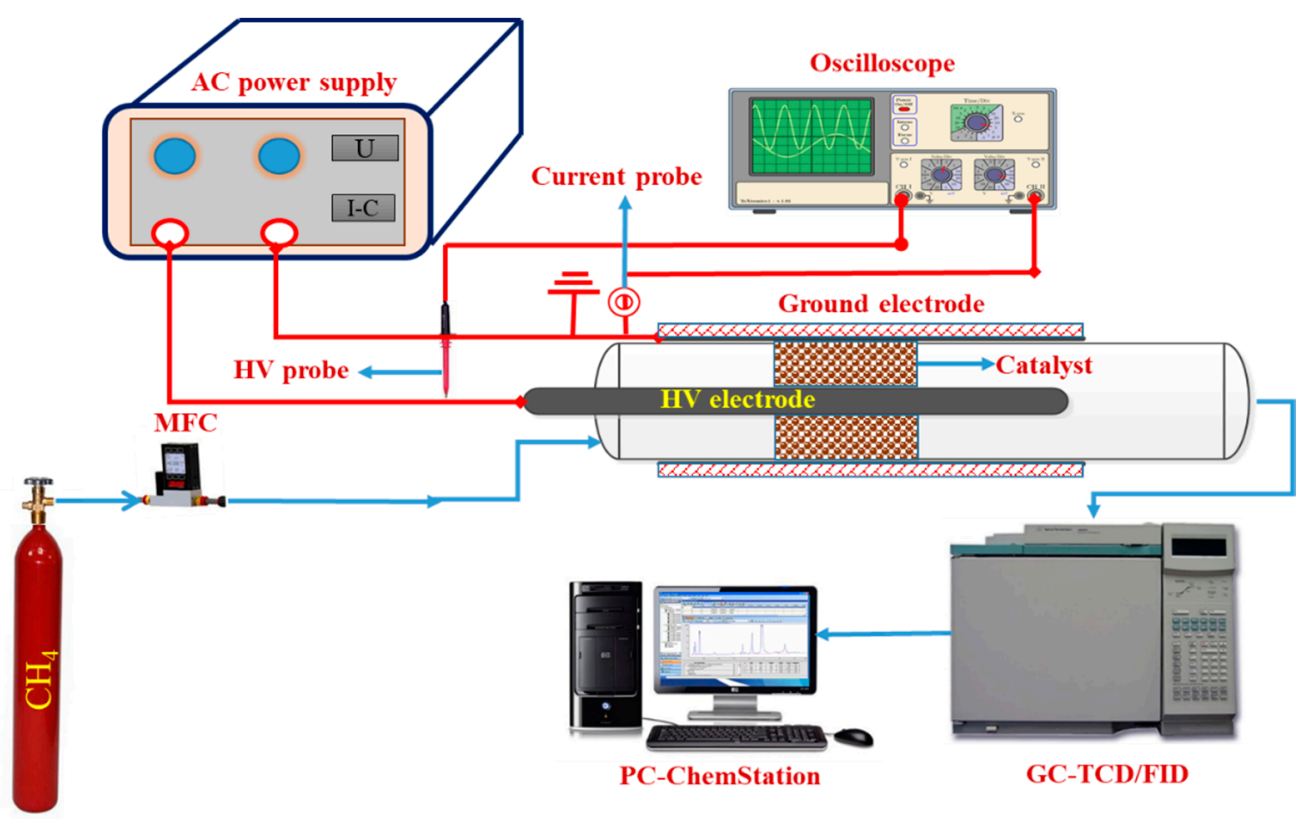

Figure 2. Schematic of fixed bed DBD catalytic-plasma reactor setup for methane cracking.

The plasma-catalytic performance was monitored for methane conversion, $\mathrm{H}_{2}$ selectivity, specific input energy (SIE) and DBD energy efficiency (EE) using the following equations (Equations (1)-(4)).

$$
\begin{gathered}
\mathrm{CH}_{4} \text { conversion }\left(\mathrm{X}_{\mathrm{CH}_{4}}\right) \%=\left[\frac{\left(\mathrm{nCH}_{4}\right)_{\text {converted }}}{\left(\mathrm{nCH}_{4}\right)_{\text {feed }}} \times 100\right] \\
\mathrm{H}_{2} \text { selectivity }\left(\mathrm{S}_{\mathrm{H}_{2}}\right) \%=\left[\frac{\left(\mathrm{nH}_{2}\right)_{\text {produced }}}{\left(2 \times \mathrm{nCH}_{4}\right)_{\text {conversion }}} \times 100\right] \\
\mathrm{SIE}\left(\frac{\mathrm{J}}{\mathrm{mL}}\right)=\left[\frac{\mathrm{P}_{\text {in }}\left(\mathrm{J} \mathrm{sec}^{-1}\right)}{\text { Total feed flow rate }\left(\mathrm{mL} \mathrm{min}^{-1}\right)}\right] \times \frac{60 \mathrm{sec}}{1 \mathrm{~min}} \\
\mathrm{EE}\left(\frac{\mathrm{mmol}}{\mathrm{kJ}}\right)=\left[\frac{\left(\mathrm{nCH}_{4}+\mathrm{nCO}_{2}\right)_{\text {converted }}\left(\mathrm{mmol} \mathrm{min}^{-1}\right)}{\mathrm{P}_{\text {in }}\left(\mathrm{kJ} \mathrm{min}^{-1}\right)}\right]
\end{gathered}
$$

where $\mathrm{n}=$ molar fraction of the gases. Feed flow rate was quantified in $\mathrm{mL} \mathrm{min}^{-1}$ was transformed into $\mathrm{mmol} \mathrm{min} \mathrm{m}^{-1}$ applying the conditions; temperature $\mathrm{T}=25^{\circ} \mathrm{C}, \mathrm{p}=1 \mathrm{~atm}$ along with a conversion factor, $1 \mathrm{mmol}=24.04 \mathrm{~mL}$ [34]. The calculation of the $P_{\text {in }}$ calculation is reported elsewhere [34]. The experiments were replicated to minimise experimental errors.

\section{Results and Discussion}

\subsection{Physicochemical Properties of the Catalyst}

Figure 3 illustrates the XRD pattern for synthesising $\mathrm{MgAl}_{2} \mathrm{O}_{4}$ and $10 \mathrm{wt} \% \mathrm{Ni} / \mathrm{MgAl}_{2} \mathrm{O}_{4}$. The $\mathrm{MgAl}_{2} \mathrm{O}_{4}$ spinel is identified for the JCPDS\# 72-6947, showing a single spinel cubic phase and prominent peaks are found at $19^{\circ}(111), 37^{\circ}(220), 38.7^{\circ}(311), 44.9^{\circ}(400), 55.9^{\circ}, 59.6^{\circ}$ and $65.5^{\circ}(440)$, and are in good agreement with the literature [35]. It also shows the space group (227:Fd-3m), the crystallite sized (average) is recorded at $10.3 \mathrm{~nm}$. In addition, hexagonal structure $\mathrm{NiO}$ is detected for the JCPDS \# 44-1159 having major peaks at $37.5^{\circ}, 43.9^{\circ}$ and $63^{\circ}$ with miller indices of (101), (012) and (110) correspondingly [36]. The space group for hexagonal $\mathrm{NiO}$ is $\mathrm{R}-3 \mathrm{~m}(166)$ and active phase is $\mathrm{NiO}^{2+}$ [37]. 
The crystallite size is $9.7 \mathrm{~nm}$ for $\mathrm{NiO}$, and the finer crystallite size depicts the formation of a uniform structure catalyst and dispersion over support $\mathrm{MgAl}_{2} \mathrm{O}_{4}$.

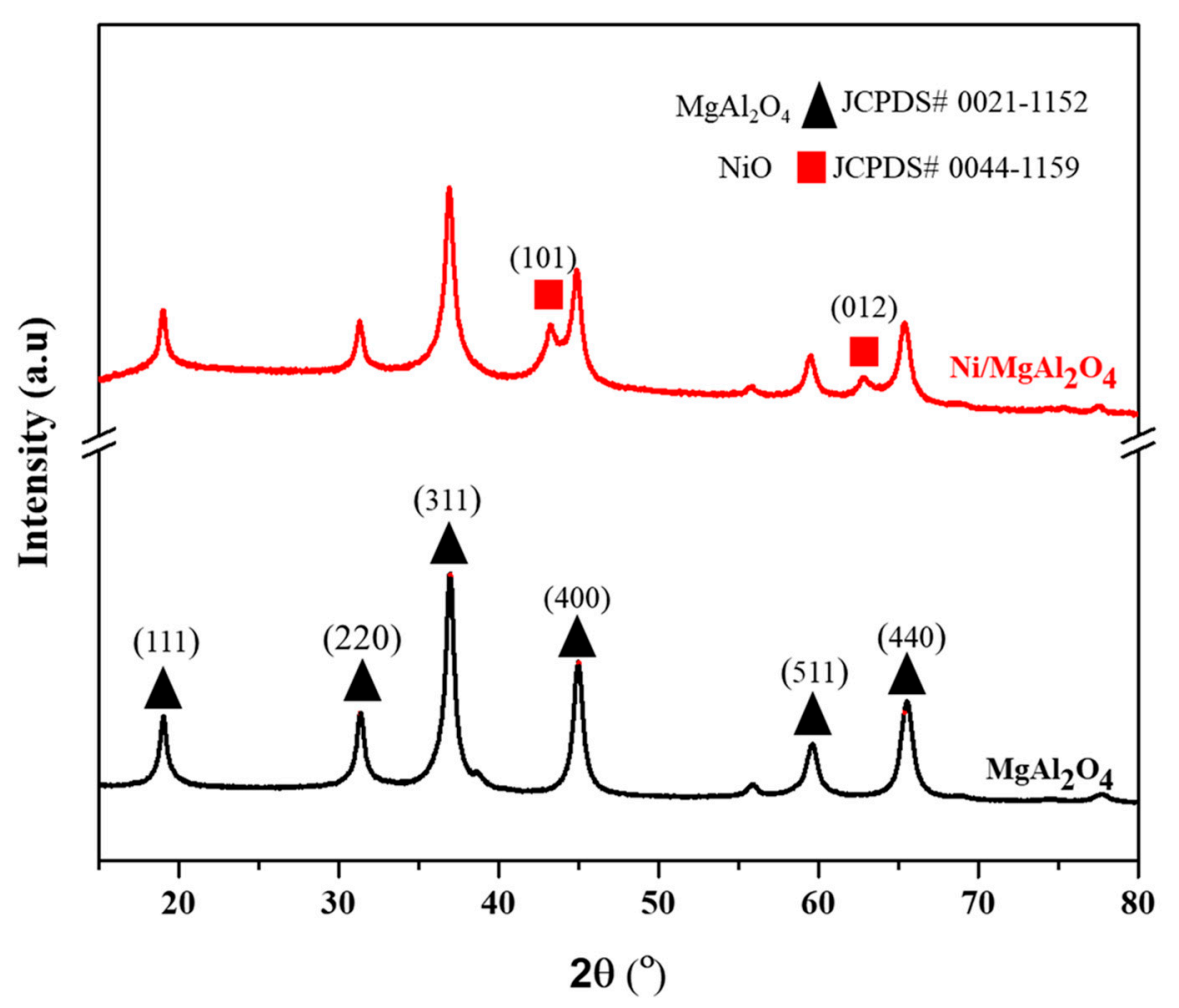

Figure 3. XRD pattern of synthesized $\mathrm{MgAl}_{2} \mathrm{O}_{4}$ and $\mathrm{Ni} / \mathrm{MgAl}_{2} \mathrm{O}_{4}$.

The surface morphology of $\mathrm{MgAl}_{2} \mathrm{O}_{4}$ and $\mathrm{Ni} / \mathrm{MgAl}_{2} \mathrm{O}_{4}$ is examined using the SEM with magnifications of $5 \mu \mathrm{m}$ and $500 \mathrm{~nm}$ and presented in Figure 4. The $\mathrm{MgAl}_{2} \mathrm{O}_{4}$ shows the fine particles with spherical structure, and some particles exhibited the worm-like shapes Figure $4 a, b$ [38]. The two different morphologies of the $\mathrm{MgAl}_{2} \mathrm{O}_{4}$ offers a comprehensive and uniform distribution of $\mathrm{Ni}$ over the surface depicted in Figure $4 \mathrm{c}$,d. The porous structure of $\mathrm{MgAl}_{2} \mathrm{O}_{4}$ offers to diffuse the $\mathrm{Ni}$ inside the pores and create actives sites. It may also assist the reactant gas and plasma species interaction later in the plasma-catalytic process.

The elemental analysis of $\mathrm{MgAl}_{2} \mathrm{O}_{4}$ and $10 \mathrm{wt} \% \mathrm{Ni} / \mathrm{MgAl}_{2} \mathrm{O}_{4}$ are demonstrated in Figure $5 \mathrm{a}, \mathrm{b}$. The significant elements $\mathrm{O}, \mathrm{Mg}$ and $\mathrm{Al}$, were found, and the composition is exhibited inset table and spectrum of Figure $5 \mathrm{a}$. While $10 \mathrm{wt} \% \mathrm{Ni} / \mathrm{MgAl}_{2} \mathrm{O}_{4}$ shows $\mathrm{Ni}$ along with $\mathrm{O}, \mathrm{Al}$ and $\mathrm{Mg}$, which is evident in the presence of $\mathrm{Ni}$ in the reported catalyst. The extra peaks without identification are due to the carbon tape and gold coating before the SEM/EDX analysis.

The TGA for $10 \mathrm{wt} \% \mathrm{Ni} / \mathrm{MgAl}_{2} \mathrm{O}_{4}$ is undertaken to analyse the thermal stability of the prepared samples, as shown in Figure 6. The $6 \%$ weight loss under $300{ }^{\circ} \mathrm{C}$ is observed, and it is ascribed to the moisture and volatile matters depicted in Figure 6, column A. In column B, which temperature is more significant than $300{ }^{\circ} \mathrm{C}$ demonstrated no weight loss further to $900{ }^{\circ} \mathrm{C}$. This analysis revealed that the synthesised catalyst is stable for the plasma-catalytic operation for methane cracking in mild conditions [39]. The unstable catalyst may lead to phase modification and sintering later in the methane cracking reactions [40]. 

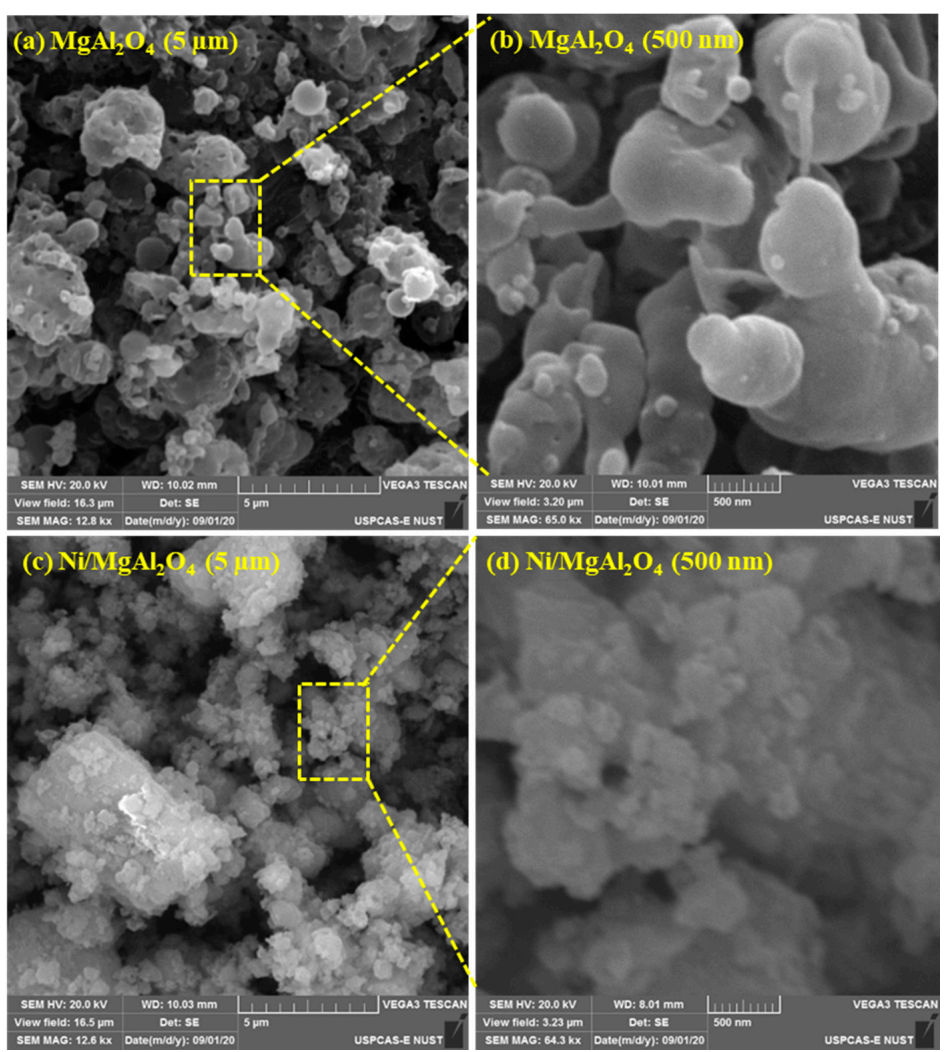

Figure 4. SEM micrograph of synthesised fresh samples; (a,b) $\mathrm{MgAl}_{2} \mathrm{O}_{4}$ (c,d) $10 \mathrm{wt} \% \mathrm{Ni} / \mathrm{MgAl}_{2} \mathrm{O}_{4}$ having $5 \mu \mathrm{m}$ and $500 \mathrm{~nm}$ of magnification.
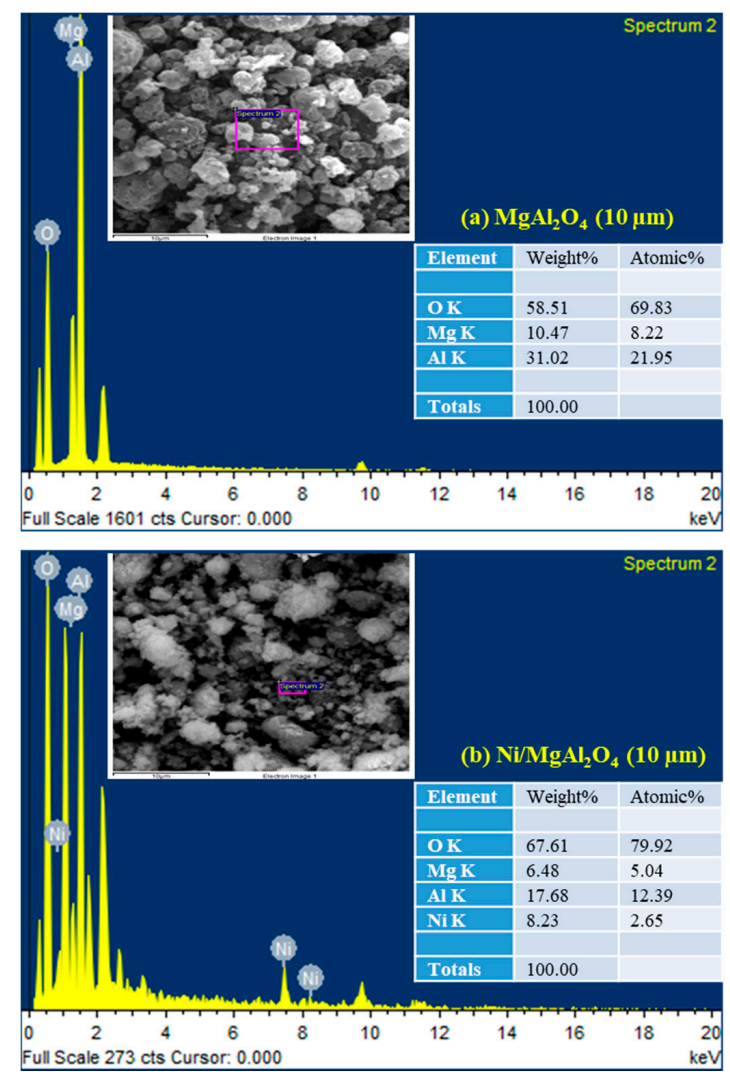

Figure 5. (a) EDX elemental analysis of (a) $\mathrm{MgAl}_{2} \mathrm{O}_{4}(\mathbf{b}) 10 \mathrm{wt} \% \mathrm{Ni} / \mathrm{MgAl}_{2} \mathrm{O}_{4}$ of using point ID technique. 


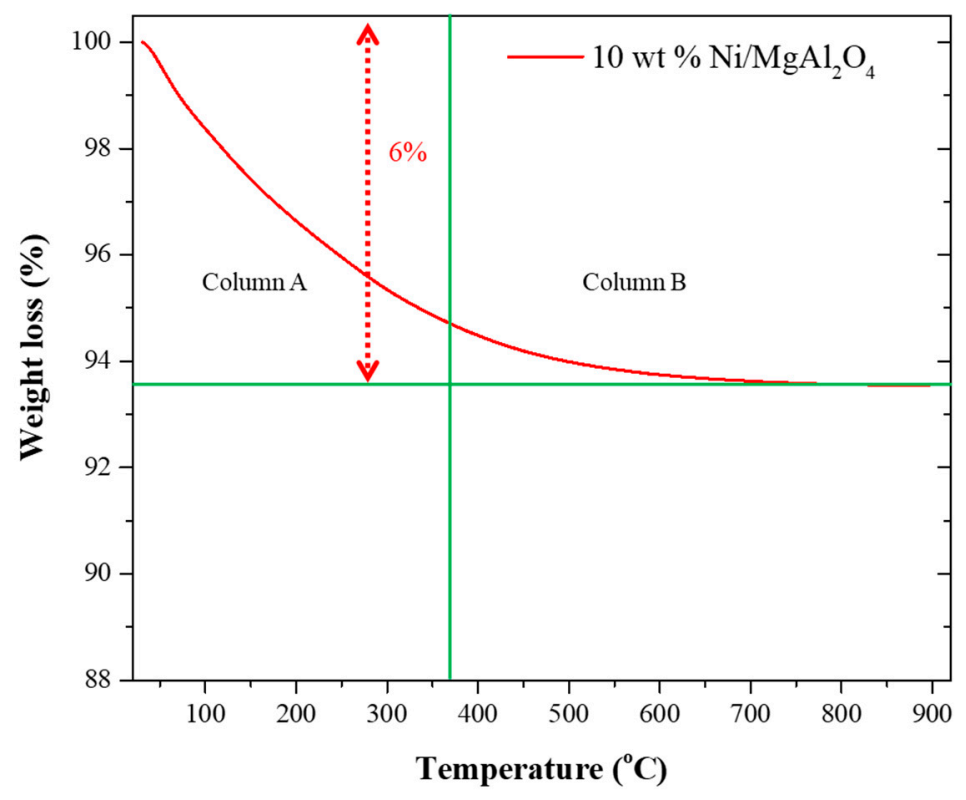

Figure 6. TGA analysis of fresh $10 \mathrm{wt} \% \mathrm{Ni} / \mathrm{MgAl}_{2} \mathrm{O}_{4}$.

\subsection{Plasma-Catalytic Methane Cracking}

\subsubsection{Plasma and Plasma-Catalytic Test and Reaction Mechanism}

The $\mathrm{CH}_{4}$ cracking is undertaken for performance analysis of plasma and plasma-catalysis presented in Figure 7. The $\mathrm{CH}_{4}$ conversion for plasma, $\mathrm{MgAl}_{2} \mathrm{O}_{4}$ and $\mathrm{Ni} / \mathrm{Mgal}_{2} \mathrm{O}_{4}$ is recorded as $65 \%$, $73 \%$ and $80 \%$ respectively at the same experimental conditions (Figure 7a). The plasma only $\mathrm{CH}_{4}$ conversion is lower as compared to the plasma-catalytic reaction. Plasma only reaction occurs due to the electron-induced dissociation of $\mathrm{CH}_{4}$, which is independent of reaction temperature [41]. The $\mathrm{CH}_{4}$ molecules collide with an energetic electron in the plasma discharge zone at discharge volume $\left(\mathrm{V}_{\mathrm{D}}\right)$ of $13.5 \mathrm{~cm}^{3}$ and start to dissociate while overcoming the required dissociation energy of $4.5 \mathrm{eV}$ [22,42]. In plasma only electron- $\mathrm{CH}_{4}$ interaction is induced, which led to the dissociation reactions and product formation reactions are as follows:

Dissociation reactions ((R2)-(R4))

$$
\begin{aligned}
\mathrm{e}^{-}+\mathrm{CH}_{4} & \rightarrow \mathrm{CH}_{3}^{*}+\mathrm{H}^{*}+\mathrm{e}^{-} \\
\mathrm{e}^{-}+\mathrm{CH}_{3}^{*} & \rightarrow \mathrm{CH}_{2}^{*}+\mathrm{H}^{*}+\mathrm{e}^{-} \\
\mathrm{e}^{-}+\mathrm{CH}_{2}^{*} & \rightarrow \mathrm{CH}^{*}+\mathrm{H}^{*}+\mathrm{e}^{-}
\end{aligned}
$$

Gaseous product formation reactions ((R5)-(R8))

$$
\begin{aligned}
& \mathrm{H}^{*}+\mathrm{H}^{*} \rightarrow \mathrm{H}_{2} \\
& \mathrm{CH}_{3}^{*}+\mathrm{CH}_{3}^{*} \rightarrow \mathrm{C}_{2} \mathrm{H}_{6} \\
& \mathrm{CH}_{2}^{*}+\mathrm{CH}_{2}^{*} \rightarrow \mathrm{C}_{2} \mathrm{H}_{4} \\
& \mathrm{CH}^{*}+\mathrm{CH}^{*} \rightarrow \mathrm{C}_{2} \mathrm{H}_{2}
\end{aligned}
$$




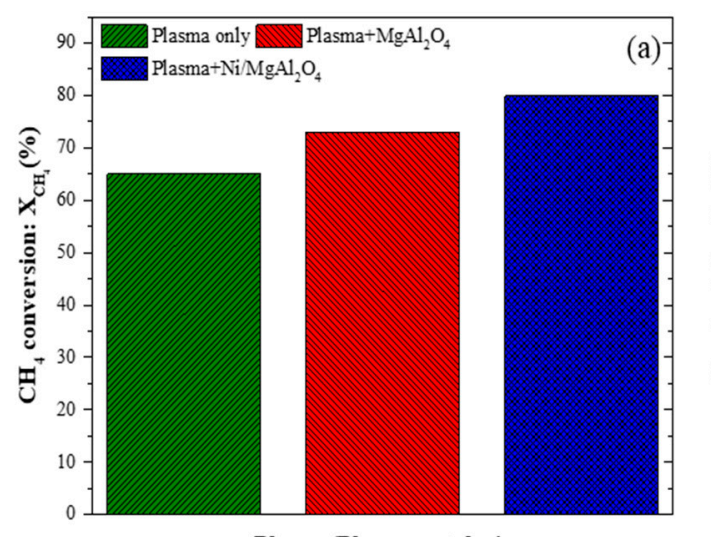

Plasma/Plasma-catalysis

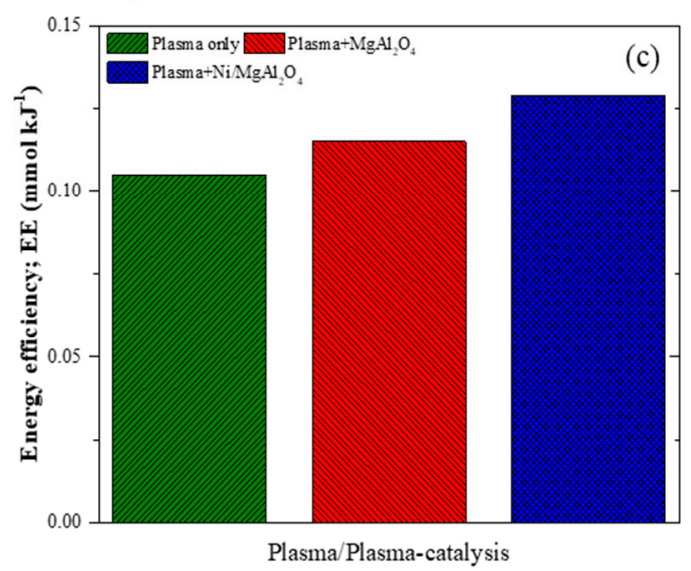

(c)

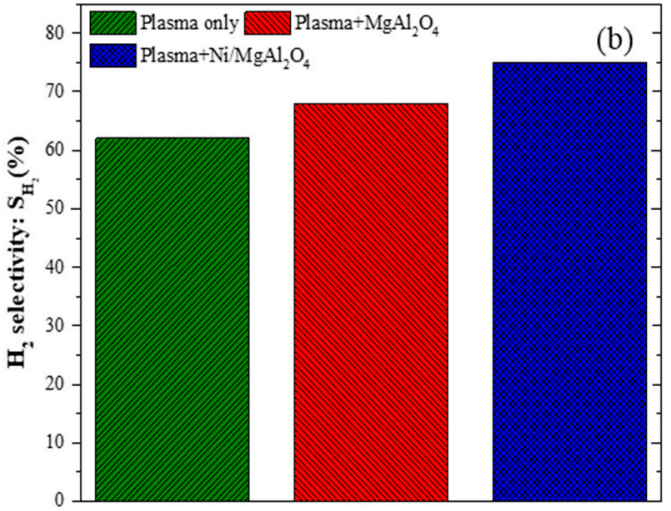

Plasma/Plasma-catalysis

Figure 7. Plasma/plasma-catalyst activity: (a) $\mathrm{X}_{\mathrm{CH} 4}$ conversion (b) $\mathrm{S}_{\mathrm{H} 2}$ selectivity (c) $\mathrm{EE}$; GHSV $=364 \mathrm{~h}^{-1}$, specific input energy $(\mathrm{SIE})=300 \mathrm{~J} \mathrm{~mL}^{-1}$, loading of catalyst $=0.5 \mathrm{~g}, \mathrm{~T}=350{ }^{\circ} \mathrm{C}$, discharge gap $\left(D_{\text {gap }}\right)=03 \mathrm{~mm}$, discharge length $\left(\mathrm{D}_{\mathrm{L}}\right)=20 \mathrm{~cm}$, discharge volume $\left(\mathrm{V}_{\mathrm{D}}\right)$ without catalyst: $13.5 \mathrm{~cm}^{3}, \mathrm{~V}_{\mathrm{D}}$ with catalyst loading $=9.75 \mathrm{~cm}^{3}$.

While loading the catalyst, $\mathrm{CH}_{4}$ conversion is improving for $\mathrm{MgAl}_{2} \mathrm{O}_{4}(73 \%)$ and $\mathrm{Ni} / \mathrm{MgAl}_{2} \mathrm{O}_{4}$ (80\%). The catalyst loading improves the $\mathrm{CH}_{4}$ conversion in both cases. In $\mathrm{Ni}$ loaded $\mathrm{MgAl}_{2} \mathrm{O}_{4}$ shows the highest conversion of $\mathrm{CH}_{4}$. The plasma produces hot spots on the catalyst, assist the $\mathrm{Ni}$ reduction, also changes catalyst functions, and reduce activation barrier due to gas heating effect [43]. While catalyst enriches the electric field, boost micro discharges and alters the discharge behaviour of DBD plasma. The catalyst-plasma interaction gives surplus effects called synergistic effect, which improves the conversion of $\mathrm{CH}_{4}$ and $\mathrm{EE}$ of DBD catalytic reactor. The $\mathrm{MgAl}_{2} \mathrm{O}_{4}$ as a support material is mechanically stable and has porous structure confirmed by SEM, assist in activating $\mathrm{CH}_{4}$, and improve the DBD plasma discharge behaviour. Ni further assists the $\mathrm{CH}_{4}$ activation due to active sites, activated by plasma give more surplus effect and enhanced the conversion by $15 \%$. The plasma only and catalyst loaded DBD system shows the difference in the conversion of $\mathrm{CH}_{4}$ and activity at certain level justifying by the synergistic effect. Unlike thermal catalysis, plasma-catalysis is not purely temperature dependent reaction. The energetic electron effect on the activation of reactant contributes more than catalytic effect [44]. However, the product selectivity in many cases is improved more as compare to conventional catalysis [45].

The $\mathrm{H}_{2}$ and $\mathrm{C}_{\mathrm{x}} \mathrm{H}_{\mathrm{x}}$ formation after the recombination of $\mathrm{H}^{*}$ and $\mathrm{CH}_{\mathrm{X}}$ in governing steps [22]. The $\mathrm{H}_{2}$ selectivity is noted $62 \%$ (Figure $7 \mathrm{~b}$ ), and some traces of $\mathrm{C}_{2} \mathrm{H}_{6}(1.5 \%)$ and $\mathrm{C}_{2} \mathrm{H}_{4}(1 \%)$ are also analysed in GC-FID for plasma only reaction. The $\mathrm{H}_{2}$ selectivity of $\mathrm{MgAl}_{2} \mathrm{O}_{4}$ and $\mathrm{Ni} / \mathrm{MgAl}_{2} \mathrm{O}_{4}$ is $68 \%$ and $75 \%$ respectively (Figure $7 \mathrm{~b}$ ). The enhanced $\mathrm{H}_{2}$ selectivity is explained in the plasma-catalyst interaction mechanism. The undetected $\mathrm{C}_{\mathrm{x}} \mathrm{H}_{\mathrm{x}}$ might be the balance for the $\mathrm{H}_{2}$ and carbon balance in the product analysis due to the limitation of the analysis technique. The EE is lowest for plasma 
only $\left(0.105 \mathrm{mmol} \mathrm{kJ}^{-1}\right)$ while $\mathrm{MgAl}_{2} \mathrm{O}_{4}\left(0.115 \mathrm{mmol} \mathrm{kJ}^{-1}\right)$ and $\mathrm{Ni} / \mathrm{MgAl}_{2} \mathrm{O}_{4}\left(0.13 \mathrm{mmol} \mathrm{kJ}{ }^{-1}\right)$ shows improvement in the EE due to the higher conversion of $\mathrm{CH}_{4}$ at constant input power (Figure 7c). The combined effect of plasma and catalyst enhances the EE of the reaction, and hence it is suitable for $\mathrm{CH}_{4}$ cracking in plasma-catalytic systems to improve EE over $\mathrm{MgAl}_{2} \mathrm{O}_{4}$ stable catalyst in mild conditions.

The proposed reaction mechanism for plasma-catalytic $\mathrm{CH}_{4}$ cracking is demonstrated in Figure 8 . It can be observed from the $\mathrm{H}_{2}$ selectivity about the reaction mechanism. The activation of $\mathrm{CH}_{4}$ to methyl radical $\mathrm{CH}_{3}{ }^{*}$ and further breakdown in the presence of plasma while attachment to the metal (M, Ni). Similarly, further breakdown leads to the complete dissociation of the C-H bond to form $\mathrm{C}^{*}$ and $\mathrm{H}^{*}$. While the recombination of $\mathrm{H}^{*}$ formed $\mathrm{H}_{2}$ and released metal (M) [46]. At the same time, the traces of $\mathrm{C}_{2} \mathrm{H}_{6}$ has produced from the recombination of $\mathrm{CH}_{3}{ }^{*}$ radicals. There are other possible routes for the formation of HCs, but the analysis of the product is more suitable for proposed pathways.

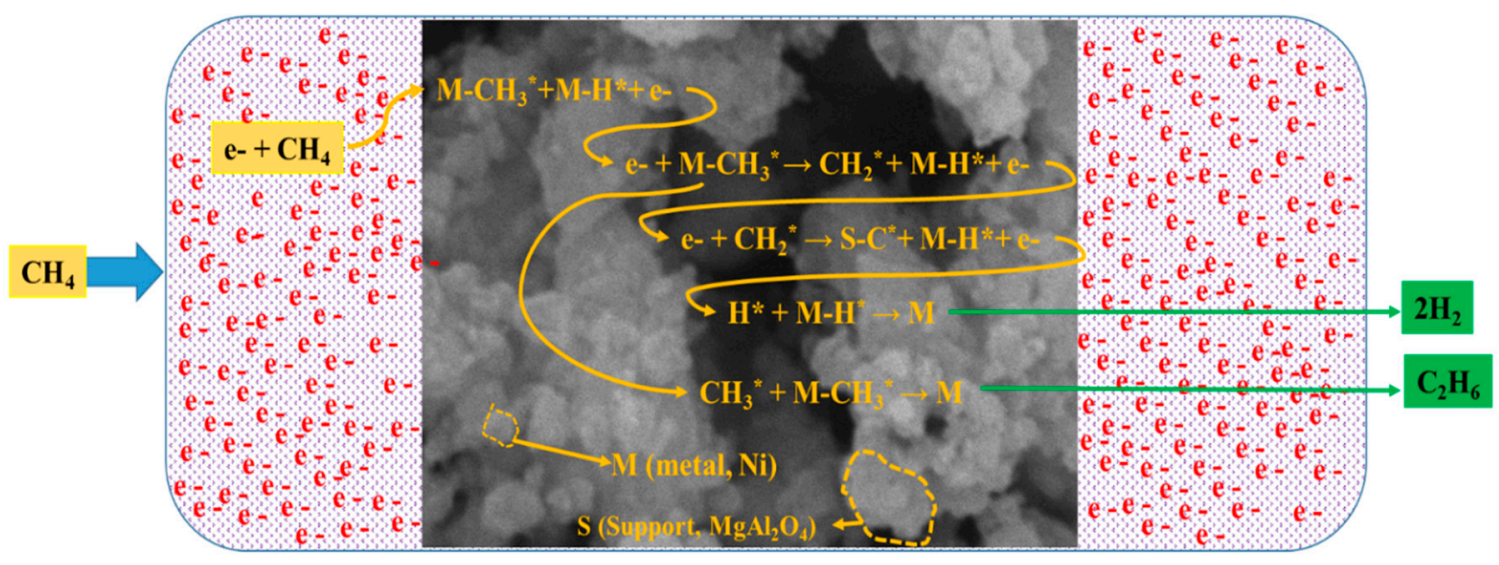

Figure 8. Proposed reaction mechanism for plasma-catalytic methane cracking over $\mathrm{Ni} / \mathrm{MgAl}_{2} \mathrm{O}_{4}$.

\subsubsection{Time on-Stream Analysis of $\mathrm{Ni} / \mathrm{MgAl}_{2} \mathrm{O}_{4}$}

The stability of the plasma-catalytic $\mathrm{CH}_{4}$ cracking on $\mathrm{Ni} / \mathrm{MgAl}_{2} \mathrm{O}_{4}$ catalyst is presented in Figure 9. The $\mathrm{CH}_{4}$ conversion and $\mathrm{H}_{2}$ selectivity being partially declining along with the TOS. The $\mathrm{CH}_{4}$ conversion above $75 \%$ while sustaining the $\mathrm{EE}$ above $0.125 \mathrm{mmol} \mathrm{kJ}{ }^{-1}$. Along with the TOS the total reduction in the conversion of $\mathrm{CH}_{4}$, and $\mathrm{H}_{2}$ selectivity is only $-5 \%$ and $-4 \%$, respectively. The negative sign indicates the reduction in the conversion and selectivity. Similar trends can be observed for EE in the $16 \mathrm{~h}$ TOS. The stability is mostly attributed to the activation of $\mathrm{NiO}$ particles due to plasma species and instant heating. The impurities in the catalyst are also removed by plasma in catalyst expose to plasma [47]. The catalyst activation assists in the $\mathrm{CH}_{4}$ activation as proposed in the possible reaction mechanism routes. Further, the breakdown of the methyl radical is also assisted by the plasma-catalyst interface while inhibiting the recombination of methyl radical, which is also observed the product analysis of in basic screening [43]. The plasma-catalyst interface improves many aspects $\operatorname{since~} \mathrm{MgAl}_{2} \mathrm{O}_{4}$ is mechanically stable support material and $\mathrm{NiO}$ also assist the $\mathrm{Ni}$ dispersion. The selectivity of $\mathrm{H}_{2}$ is also ascribed to the highly basic nature of the $\mathrm{MgAl}_{2} \mathrm{O}_{4}$, which improves the $\mathrm{CH}_{\mathrm{x}}{ }^{*}$ adsorption and assist in the activation and further breakdown [48-50]. The $\mathrm{CH}_{4}$ cracking on plasma-catalytic to $\mathrm{CH}_{\mathrm{x}}$ heavily depends on the $\mathrm{Ni} / \mathrm{MgAl}_{2} \mathrm{O}_{4}$ interaction providing the higher coordinate sites in the plasma-catalytic interface, which is expected to achieve in the case for longer TOS. The plasma-catalytic interface gave reasonable stability and improved $\mathrm{EE}$ for $\mathrm{CH}_{4}$ cracking in catalytic-DBD reactor condition. 


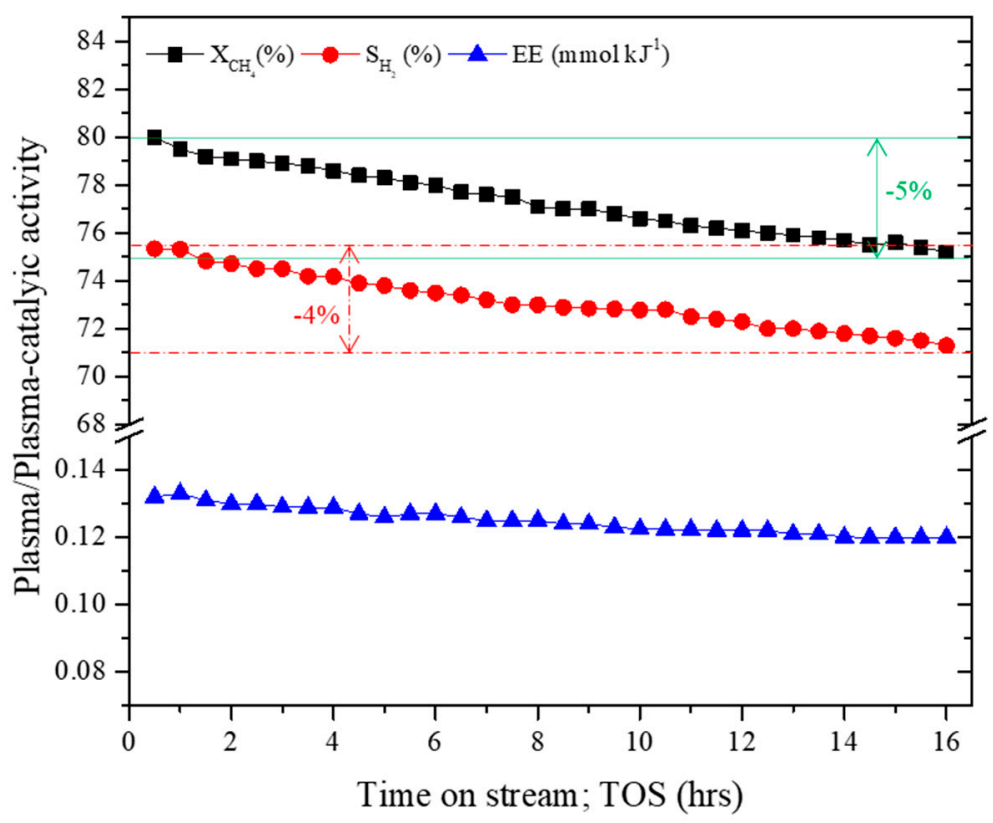

Figure 9. Analysis of time on stream (TOS) (16 h) on $\mathrm{X}_{\mathrm{CH} 4}(\%), \mathrm{S}_{\mathrm{H} 2}(\%)$ and $\mathrm{EE} \mathrm{mmol} \mathrm{kJ}{ }^{-1}$. Experimental conditions: GHSV $=364 \mathrm{~h}^{-1}$, specific input energy $(\mathrm{SIE})=300 \mathrm{~J} \mathrm{~mL}^{-1}$, loading of catalyst $=0.5 \mathrm{~g}$, $\mathrm{T}=350{ }^{\circ} \mathrm{C}$, discharge gap $\left(\mathrm{D}_{\text {gap }}\right)=03 \mathrm{~mm}$, discharge length $\left(\mathrm{D}_{\mathrm{L}}\right)=20 \mathrm{~cm}$, discharge volume $\left(\mathrm{V}_{\mathrm{D}}\right)$ without catalyst: $13.5 \mathrm{~cm}^{3}, \mathrm{~V}_{\mathrm{D}}$ with catalyst loading $=9.75 \mathrm{~cm}^{3}$.

\subsection{Characterisation of Spent Catalyst and Reaction Mechanism}

The morphology and TGA-DTG analysis of the spent $\mathrm{Ni} / \mathrm{MgAl}_{2} \mathrm{O}_{4}$ after $16 \mathrm{~h}$ TOS is given in Figure 10. The CNTs were observed in SEM analysis (Figure 10a) of spent catalyst along carbon fibres [51]. Mostly the CNTs formed are useful for further utilisation in energy storage application [31]. The TGA analysis (Figure 10b) shows the weight less than $200^{\circ} \mathrm{C}$ is ascribed to the volatile matters, while weight lost from $200-400{ }^{\circ} \mathrm{C}$ is ascribed to the amorphous carbon. The weight loss beyond 500 is ascribed to the multiwall CNTs [52]. The CNTs can also be seen in SEM micrographs. The nature of the carbon formed is analysed using DTG profile (Figure 10b). The DTG curve at $355^{\circ} \mathrm{C}$, the peak is ascribed to the amorphous and fibrous carbon formed and ioxidized at less than $400{ }^{\circ} \mathrm{C}$ [51]. The DTG curve at $690^{\circ} \mathrm{C}$ is ascribed to multiwall CNTs with low defects and low curvature with pure sp ${ }^{2}$ structure $[53,54]$. The formed carbon is ascribed to a stable material for energy storage applications and discharge while increasing the temperature without surface modification [55]. This technology for methane cracking for simultaneous hydrogen and CNT formation is a beneficial process [56]. 


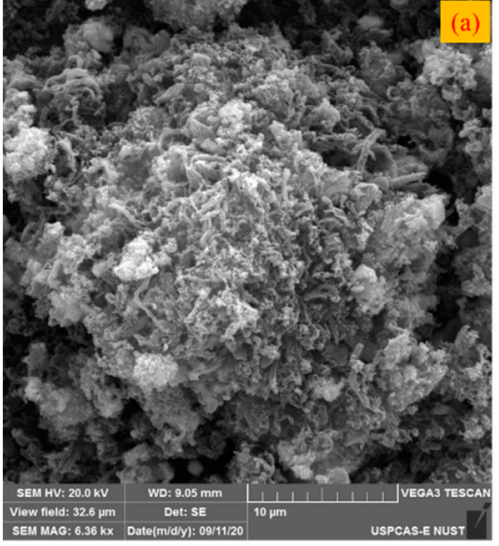

SEM micrograph of spent $\mathrm{Ni} / \mathrm{MgAl}_{2} \mathrm{O}_{4}$

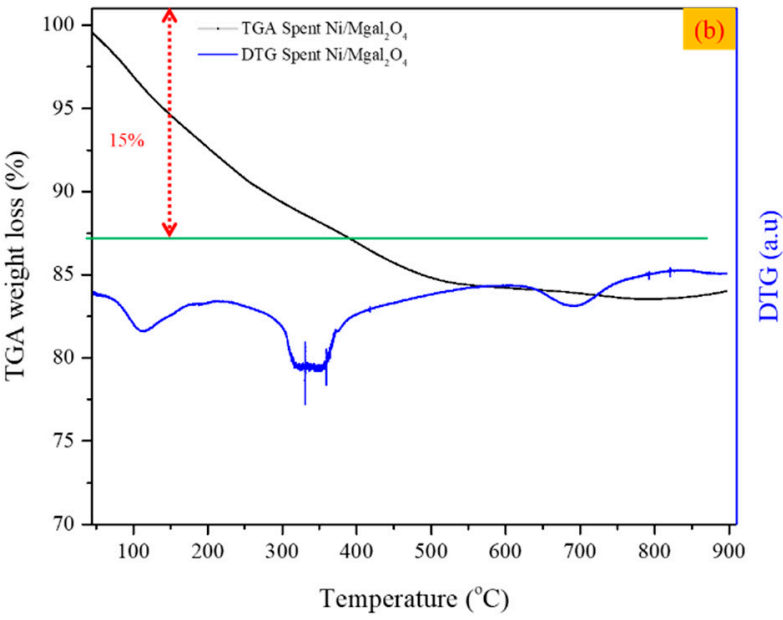

Figure 10. Spent $\mathrm{Ni} / \mathrm{MgAl}_{2} \mathrm{O}_{4}$ after $16 \mathrm{~h}$ TOS analysis (a) SEM micrograph (b) TGA-DTG analysis.

\section{Conclusions}

The $\mathrm{CH}_{4}$ cracking in catalytic DBD plasma fixed bed reactor has been studied and found that the plasma-catalytic process enhances the $\mathrm{CH}_{4}$ conversion $(80 \%)$, improved the EE of the catalytic DBD reactor. The possible interaction between plasma-catalyst enhances the discharge behaviour, active species and improve the contact time between electrons and gas molecules to dissociate and formed the products. The selectivity for $\mathrm{H}_{2}$ is improved to $75 \%$ in plasma-catalytic-DBD systems as compared to plasma only $\mathrm{CH}_{4}$ cracking (62\%). While EE also improved in such manner $0.13 \mathrm{mmol}$ $\mathrm{kJ}^{-1}$. The $16 \mathrm{~h}$ TOS stability shows a slight declined in the $\mathrm{CH}_{4}$ conversion due to the fibrous carbon and CNT formation confirmed from TGA-DTG analysis. The spent catalyst shows the formation of CNTs which are beneficial for further utilisation for energy storage systems.

The $\mathrm{CH}_{4}$ utilisation in non-thermal DBD plasma for $\mathrm{H}_{2}$ and CNTs formation is a highly desirable route for the simultaneous $\mathrm{H}_{2}$ production and storage for fuel cell applications. Further study is recommended on the cleaning of $\mathrm{H}_{2}$ in cold plasma catalytic systems via membrane or monolith reactor systems.

Author Contributions: Conceptualization, A.H.K. and N.A.S.A.; methodology, A.H.K. and M.T.M.; validation, A.K.A., S.R.N. and B.A.K.; formal analysis, A.H.K.; investigation, A.H.K.; N.A.S.A., writing-original draft preparation, A.H.K. and F.S.; writing-review and editing, A.K.A. and N.A.S.A.; supervision, N.A.S.A.; project administration and funding acquisition, A.H.K., N.A.S.A. All authors have read and agreed to the published version of the manuscript.

Funding: This research was funded by Universiti Teknologi Malaysia and the Ministry of Education, Malaysia for the financial support of this research under RUG (Research University Grant, Vot13H35) and FRGS-MRSA grant (Vot 4F988).

Acknowledgments: The authors appreciated Universiti Teknologi Malaysia and the (MOHE) Ministry of Education, Malaysia, for the financial support of this research.

Conflicts of Interest: The authors declare no conflict of interest.

\section{References}

1. Goglio, R.; Smith, W.N.; Grant, B.B.; Desjardins, R.L.; Gao, X.; Hanis, K.; Tenuta, M.; Campbell, C.A.; McConkey, B.G.; Nemecek, T.; et al. A comparison of methods to quantify greenhouse gas emissions of cropping systems in LCA. J. Clean. Prod. 2018, 172, 4010-4017. [CrossRef]

2. Salkuyeh, Y.K.; Adams, T.A. Combining coal gasification, natural gas reforming, and external carbonless heat for efficient production of gasoline and diesel with $\mathrm{CO}_{2}$ capture and sequestration. Energy Convers. Manag. 2013, 74, 492-504. [CrossRef]

3. Wang, X.; Gao, Y.; Zhang, S.; Sun, H.; Li, J.; Shao, T. Nanosecond pulsed plasma assisted dry reforming of $\mathrm{CH}_{4}$ : The effect of plasma operating parameters. Appl. Energy 2019, 243, 132-144. [CrossRef] 
4. Schwietzke, S.; Sherwood, O.A.; Bruhwiler, L.M.; Miller, J.B.; Etiope, G.; Dlugokencky, E.J.; Michel, S.E.; Arling, V.A.; Vaughn, B.H.; White, J.W.; et al. Upward revision of global fossil fuel methane emissions based on isotope database. Nature 2016, 538, 88-91. [CrossRef]

5. Razi, F.; Dincer, I. A critical evaluation of potential routes of solar hydrogen production for sustainable development. J. Clean. Prod. 2020, 264, 121582. [CrossRef]

6. Khalifeh, O.; Taghvaei, H.; Mosallanejad, A.; Rahimpour, M.R.; Shariati, A. Extra pure hydrogen production through methane decomposition using nanosecond pulsed plasma and Pt-Re catalyst. Chem. Eng. J. 2016, 294, 132-145. [CrossRef]

7. Zhang, R.; Cao, Y.; Li, H.; Zhao, Z.; Zhao, K.; Jiang, L. The role of $\mathrm{CuO}$ modified $\mathrm{La}_{0.7} \mathrm{Sr}_{0.3} \mathrm{FeO}_{3}$ perovskite on intermediate-temperature partial oxidation of methane via chemical looping scheme. Int. J. Hydrogen Energy 2020, 45, 4073-4083. [CrossRef]

8. Khoja, A.H.; Tahir, M.; Amin, N.A.S. Recent developments in non-thermal catalytic DBD plasma reactor for dry reforming of methane. Energy Convers. Manag. 2019, 183, 529-560. [CrossRef]

9. Khoja, A.H.; Anwar, M.; Shakir, S.; Mehran, M.T.; Mazhar, A.; Javed, A.; Amin, N.A.S. Thermal dry reforming of methane over $\mathrm{La}_{2} \mathrm{O}_{3}$ co-supported $\mathrm{Ni} / \mathrm{MgAl}_{2} \mathrm{O}_{4}$ catalyst for hydrogen-rich syngas production. Res. Chem. Intermed. 2020, 46, 3817-3833. [CrossRef]

10. Lašič Jurković, D.; Liu, J.-L.; Pohar, A.; Likozar, B. Methane Dry Reforming over Ni/ $\mathrm{Al}_{2} \mathrm{O}_{3}$ Catalyst in Spark Plasma Reactor: Linking Computational Fluid Dynamics (CFD) with Reaction Kinetic Modelling. Catal. Today 2020. [CrossRef]

11. Dan, M.; Mihet, M.; Lazar, M.D. Hydrogen and/or syngas production by combined steam and dry reforming of methane on nickel catalysts. Int. J. Hydrogen Energy 2020, 45, 26254-26264. [CrossRef]

12. Snoeckx, R.; Bogaerts, A. Plasma technology-A novel solution for $\mathrm{CO}_{2}$ conversion? Chem. Soc. Rev. 2017, 46, 5805-5863. [CrossRef] [PubMed]

13. Assad Munawar, M.; Hussain Khoja, A.; Hassan, M.; Liaquat, R.; Raza Naqvi, S.; Taqi Mehran, M.; Abdullah, A.; Saleem, F. Biomass ash characterization, fusion analysis and its application in catalytic decomposition of methane. Fuel 2021, 285, 119107. [CrossRef]

14. Pudukudy, M.; Yaakob, Z.; Takriff, M.S. Methane decomposition into $\mathrm{CO}_{\mathrm{x}}$ free hydrogen and multiwalled carbon nanotubes over ceria, zirconia and lanthana supported nickel catalysts prepared via a facile solid state citrate fusion method. Energy Convers. Manag. 2016, 126, 302-315. [CrossRef]

15. Mendoza-Nieto, J.A.; Vera, E.; Pfeiffer, H. Methane Reforming Process by means of a Carbonated $\mathrm{Na}_{2} \mathrm{ZrO}_{3}$ Catalyst. Chem. Lett. 2016, 45, 685-687. [CrossRef]

16. Lašič Jurković, D.; Puliyalil, H.; Pohar, A.; Likozar, B. Plasma-activated methane partial oxidation reaction to oxygenate platform chemicals over Fe, Mo, Pd and zeolite catalysts. Int. J. Energy Res. 2019, 43, 8085-8099. [CrossRef]

17. Zhang, H.; Du, C.; Wu, A.; Bo, Z.; Yan, J.; Li, X. Rotating gliding arc assisted methane decomposition in nitrogen for hydrogen production. Int. J. Hydrogen Energy 2014, 39, 12620-12635. [CrossRef]

18. da Costa Labanca, A.R. Carbon black and hydrogen production process analysis. Int. J. Hydrogen Energy 2020, 45, 25698-25707. [CrossRef]

19. Nozaki, T.; Okazaki, K. Non-thermal plasma catalysis of methane: Principles, energy efficiency, and applications. Catal. Today 2013, 211, 29-38. [CrossRef]

20. Wang, B.; Cao, X.; Yang, K.; Xu, G. Conversion of methane through dielectric-barrier discharge plasma. Front. Chem. Eng. China 2008, 2, 373-378. [CrossRef]

21. Staffell, I.; Scamman, D.; Abad, A.V.; Balcombe, P.; Dodds, P.E.; Ekins, P.; Shah, N.; Ward, K.R. The role of hydrogen and fuel cells in the global energy system. Energy Environ. Sci. 2019, 12, 463-491. [CrossRef]

22. Taghvaei, H.; Jahanmiri, A.; Rahimpour, M.R.; Shirazi, M.M.; Hooshmand, N. Hydrogen production through plasma cracking of hydrocarbons: Effect of carrier gas and hydrocarbon type. Chem. Eng. J. 2013, 226, 384-392. [CrossRef]

23. Lee, H.; Lee, D.-H.; Song, Y.-H.; Choi, W.C.; Park, Y.-K.; Kim, D.H. Synergistic effect of non-thermal plasma-catalysis hybrid system on methane complete oxidation over Pd-based catalysts. Chem. Eng. J. 2015, 259, 761-770. [CrossRef]

24. Kim, S.-S.; Kim, J.; Lee, H.; Na, B.-K.; Song, H.K. Methane conversion over nanostructured $\mathrm{Pt} / \gamma-\mathrm{Al}_{2} \mathrm{O}_{3}$ catalysts in dielectric-barrier discharge. Korean J. Chem. Eng. 2005, 22, 585-590. [CrossRef] 
25. Indarto, A. Hydrogen production from methane in a dielectric barrier discharge using oxide zinc and chromium as catalyst. J. Chin. Inst. Chem. Eng. 2008, 39, 23-28. [CrossRef]

26. Son, I.H.; Kwon, S.; Park, J.H.; Lee, S.J. High coke-resistance $\mathrm{MgAl}_{2} \mathrm{O}_{4}$ islands decorated catalyst with minimizing sintering in carbon dioxide reforming of methane. Nano Energy 2016, 19, 58-67. [CrossRef]

27. Li, G.; Cheng, H.; Zhao, H.; Lu, X.; Xu, Q.; Wu, C. Hydrogen production by $\mathrm{CO}_{2}$ reforming of $\mathrm{CH}_{4}$ in coke oven gas over $\mathrm{Ni}-\mathrm{Co} / \mathrm{MgAl}_{2} \mathrm{O}_{4}$ catalysts. Catal. Today 2018, 318, 46-51. [CrossRef]

28. Khoja, A.H.; Tahir, M.; Saidina Amin, N.A. Process optimization of DBD plasma dry reforming of methane over $\mathrm{Ni} / \mathrm{La}_{2} \mathrm{O}_{3}-\mathrm{MgAl}_{2} \mathrm{O}_{4}$ using multiple response surface methodology. Int. J. Hydrogen Energy 2019, 44, 11774-11787. [CrossRef]

29. Guo, J.J.; Lou, H.; Zhao, H.; Chai, D.F.; Zheng, X.M. Dry reforming of methane over nickel catalysts supported on magnesium aluminate spinels. Appl Catal A-Gen 2004, 273, 75-82. [CrossRef]

30. Khoja, A.H.; Tahir, M.; Saidina Amin, N.A. Evaluating the Performance of a Ni Catalyst Supported on $\mathrm{La}_{2} \mathrm{O}_{3}-\mathrm{MgAl}_{2} \mathrm{O}_{4}$ for Dry Reforming of Methane in a Packed Bed Dielectric Barrier Discharge Plasma Reactor. Energy Fuels 2019, 33, 11630-11647. [CrossRef]

31. Liu, W.; Yuan, H. Simultaneous production of hydrogen and carbon nanotubes from cracking of a waste cooking oil model compound over Ni-Co/SBA-15 catalysts. Int. J. Energy Res. 2020. [CrossRef]

32. Charisiou, N.D.; Siakavelas, G.; Papageridis, K.N.; Baklavaridis, A.; Tzounis, L.; Avraam, D.G.; Goula, M.A. Syngas production via the biogas dry reforming reaction over nickel supported on modified with $\mathrm{CeO}_{2}$ and/or $\mathrm{La}_{2} \mathrm{O}_{3}$ alumina catalysts. J. Nat. Gas Sci. Eng. 2016, 31, 164-183. [CrossRef]

33. Jamil, U.; Husain Khoja, A.; Liaquat, R.; Raza Naqvi, S.; Nor Nadyaini Wan Omar, W.; Aishah Saidina Amin, N. Copper and calcium-based metal organic framework (MOF) catalyst for biodiesel production from waste cooking oil: A process optimization study. Energy Convers. Manag. 2020, 215, 112934. [CrossRef]

34. Khoja, A.H.; Tahir, M.; Amin, N.A.S. Dry reforming of methane using different dielectric materials and DBD plasma reactor configurations. Energy Convers. Manag. 2017, 144, 262-274. [CrossRef]

35. Sanjabi, S.; Obeydavi, A. Synthesis and characterization of nanocrystalline $\mathrm{MgAl}_{2} \mathrm{O}_{4}$ spinel via modified sol-gel method. J. Alloy. Compd. 2015, 645, 535-540. [CrossRef]

36. Nishikawa, H.; Kawamoto, D.; Yamamoto, Y.; Ishida, T.; Ohashi, H.; Akita, T.; Honma, T.; Oji, H.; Kobayashi, Y.; Hamasaki, A.; et al. Promotional effect of Au on reduction of Ni(II) to form Au-Ni alloy catalysts for hydrogenolysis of benzylic alcohols. J. Catal. 2013, 307, 254-264. [CrossRef]

37. Wang, C.; Sun, N.; Zhao, N.; Wei, W.; Zhao, Y. Template-free preparation of bimetallic mesoporous $\mathrm{Ni}-\mathrm{Co}-\mathrm{CaO}-\mathrm{ZrO}_{2}$ catalysts and their synergetic effect in dry reforming of methane. Catal. Today 2017, 281, 268-275. [CrossRef]

38. Malekabadi, M.A.; Mamoory, R.S. Low-temperature synthesis of micro/nano Lithium Fluoride added magnesium aluminate spinel. Ceram. Int. 2018, 44, 20122-20131. [CrossRef]

39. Ray, D.; Reddy, P.M.K.; Subrahmanyam, C. Ni-Mn $/ \gamma-\mathrm{Al}_{2} \mathrm{O}_{3}$ assisted plasma dry reforming of methane. Catal. Today 2018, 309, 212-218. [CrossRef]

40. Wang, Q.; Cheng, Y.; Jin, Y. Dry reforming of methane in an atmospheric pressure plasma fluidized bed with $\mathrm{Ni} / \gamma-\mathrm{Al}_{2} \mathrm{O}_{3}$ catalyst. Catal. Today 2009, 148, 275-282. [CrossRef]

41. Heintze, M.; Pietruszka, B. Plasma catalytic conversion of methane into syngas: The combined effect of discharge activation and catalysis. Catal. Today 2004, 89, 21-25. [CrossRef]

42. Jiang, T.; Li, Y.; Liu, C.J.; Xu, G.H.; Eliasson, B.; Xue, B.Z. Plasma methane conversion using dielectric-barrier discharges with zeolite A. Catal. Today 2002, 72, 229-235. [CrossRef]

43. Khoja, A.H.; Tahir, M.; Amin, N.A.S. Cold plasma dielectric barrier discharge reactor for dry reforming of methane over $\mathrm{Ni} / \gamma-\mathrm{Al}_{2} \mathrm{O}_{3}-\mathrm{MgO}$ nanocomposite. Fuel Process. Technol. 2018, 178, 166-179. [CrossRef]

44. Neyts, E.C.; Ostrikov, K.K.; Sunkara, M.K.; Bogaerts, A. Plasma catalysis: Synergistic effects at the nanoscale. Chem. Rev. 2015, 115, 13408-13446. [CrossRef] [PubMed]

45. Neyts, E.C.; Ostrikov, K. Nanoscale thermodynamic aspects of plasma catalysis. Catal. Today 2015, 256, 23-28. [CrossRef]

46. Yap, D.; Tatibouët, J.-M.; Batiot-Dupeyrat, C. Catalyst assisted by non-thermal plasma in dry reforming of methane at low temperature. Catal. Today 2018, 299, 263-271. [CrossRef]

47. Liu, C.J.; Li, M.Y.; Wang, J.Q.; Zhou, X.T.; Guo, Q.T.; Yan, J.M.; Li, Y.Z. Plasma methods for preparing green catalysts: Current status and perspective. Chin. J. Catal. 2016, 37, 340-348. [CrossRef] 
48. Fan, Z.; Sun, K.; Rui, N.; Zhao, B.; Liu, C.-j. Improved activity of Ni/MgAl $\mathrm{Al}_{4}$ for $\mathrm{CO}_{2}$ methanation by the plasma decomposition. J. Energy Chem. 2015, 24, 655-659. [CrossRef]

49. Guo, J.; Lou, H.; Zhao, H.; Zheng, X. Improvement of stability of out-layer $\mathrm{MgAl}_{2} \mathrm{O}_{4}$ spinel for a $\mathrm{Ni} / \mathrm{MgAl}_{2} \mathrm{O}_{4} / \mathrm{Al}_{2} \mathrm{O}_{3}$ catalyst in dry reforming of methane. React. Kinet. Catal. Lett. 2005, 84, 93-100. [CrossRef]

50. Guo, J.; Lou, H.; Zheng, X. The deposition of coke from methane on a Ni/MgAl ${ }_{2} \mathrm{O}_{4}$ catalyst. Carbon 2007, 45, 1314-1321. [CrossRef]

51. Megía, P.J.; Calles, J.A.; Carrero, A.; Vizcaíno, A.J. Effect of the incorporation of reducibility promoters $(\mathrm{Cu}$, $\mathrm{Ce}, \mathrm{Ag}$ ) in Co/CaSBA-15 catalysts for acetic acid steam reforming. Int. J. Energy Res. 2020. [CrossRef]

52. Osman, A.I.; Blewitt, J.; Abu-Dahrieh, J.K.; Farrell, C.; Al-Muhtaseb, A.H.; Harrison, J.; Rooney, D.W. Production and characterisation of activated carbon and carbon nanotubes from potato peel waste and their application in heavy metal removal. Env. Sci. Pollut. Res. Int. 2019, 26, 37228-37241. [CrossRef] [PubMed]

53. Krishnia, L.; Kumari, R.; Kumar, V.; Singh, A.; Garg, P.; Yadav, B.S.; Tyagi, P.K. Comparative study of thermal stability of filled and un-filled multiwalled carbon nanotubes. Adv. Mater. Lett. 2016, 7, 230-234. [CrossRef]

54. Azmina, M.; Suriani, A.B.; Salina, M.; Azira, A.; Dalila, A.; Asli, N.; Rosly, J.; Nor, R.M.; Rusop, M. Variety of Bio-Hydrocarbon Precursors for the Synthesis of Carbon Nanotubes; Trans Tech Publisher: Baech, Switzerland, 2012; pp. 43-63.

55. Pudukudy, M.; Yaakob, Z.; Takriff, M.S. Methane decomposition over Pd promoted Ni/MgAl ${ }_{2} \mathrm{O}_{4}$ catalysts for the production of COx free hydrogen and multiwalled carbon nanotubes. Appl. Surf. Sci. 2015, 356, 1320-1326. [CrossRef]

56. Dong, Z.; Li, B.; Cui, C.; Qian, W.; Jin, Y.; Wei, F. Catalytic methane technology for carbon nanotubes and graphene. React. Chem. Eng. 2020, 5, 991-1004. [CrossRef]

Publisher's Note: MDPI stays neutral with regard to jurisdictional claims in published maps and institutional affiliations. 